\title{
The Role Change of College English Teachers under the Network Environment
}

\author{
Yahui Gao \\ Xi’an International University, Xi’an, Shanxi,710077
}

Keywords: network environment; teacher; College English teaching; change of the role

\begin{abstract}
As the Internet has been popularized in our country, all walks of life are closely related to it, therefore, the college English teaching is no exception. Under the network environment, the multimedia technology has been widely used in College English teaching, from which teachers and students can get more and more comprehensive learning resources. But it is noteworthy that as the independent learning ability of students has been improved in the university, and the easy access of the network resources, the role of teachers in college English teaching has gradually changed. With the expansion of learning resources, there are many new problems in the teaching of College English in the network environment. As for the teacher's role, its authority is constantly weak. This paper mainly analyzes the role of teachers in College English teaching, and explores how the teacher's role changes from the traditional role under the network environment.
\end{abstract}

\section{Introduction}

We have to admit that the network has brought great convenience to our life. The full use of network resources in the education area does solve many problems in the teaching and learning process. It is especially true for the college education which emphasis more on the students' selflearning ability, so the role of college English teacher is mostly as a guider. Through the use of multimedia technology, the teachers can help the students to have a profound understanding of the college English content and guide students to self-learning. With the network environment, the role of teachers in college English teaching gradually changed. At this point, university teachers need to be aware of this, and actively transform the role in the face of the new environment, so as to achieve the new development of college English teaching.

\section{The Characteristics of Teacher's Role in the Traditional College English Teaching}

University education different greatly from high school education, which each majors has its own professional characteristics, and the teachers also have high professional standards. At this stage, the students' thoughts have been more independent. In the traditional university teaching, especially in the college English teaching, the role of teacher is extremely important and distinctive.

In the past, English teaching has been paid much attention, so does the college English teaching. With the belief of teaching well, teachers always devote their knowledge and energy to cultivating numerous of talents for the country. In the age when the network and computer and other advanced information technology products were not so popular, teachers in the college English classroom is always the imparters of knowledge. Based on the book, they are willing to impart their own knowledge unreservedly. In the college English teaching, teachers will explain the knowledge and skills of English reading, speaking, listening, English culture and other related knowledge to the students, where the teachers play the role of the imparters. As the imparters, they will bring many benefits to the college English teaching, of course, there are flaws. On the one hand, students can get a lot of knowledge and information through their teachers. On the other hand, students may depend too much on their teachers, lacking the exercises of independent self-awareness.

In the traditional college English teaching, the face to face communication between teachers and students are often about English learning problems, and at the same time, the students are very cute, holding a respect belief towards their teachers. In the teaching process, students who have questions can directly seek help from their teachers. 
The communications between them are more frequently and they are more closer to each other. Besides of knowledge teaching, teachers also manage the students' English learning strictly, such as students' English homework, and how much they understand of the important points. It can be said, compared with the current new environment, in particular, the current network environment, there are more accompany between the teachers and students in the traditional English teaching. Therefore, teachers serve as mentors of the students.

From the above analysis of the characteristics of teachers' role in the traditional English teaching, we can see that it has both the pros and cons to the English learning. The above analysis does not show that the role of teachers in traditional college English teaching is better or worse than that of in the current network environment. Teachers' roles play different functions in the different contexts, and therefore the emphases are different. However, under the network environment, the role of teachers in college English teaching should change. During this transitional process, teachers should keep the good sides, and try new roles, so that students can integrate into the college English teaching.

\section{The Role Change of College English Teachers under the Network Environment}

College English teaching should change with the development of times. Especially under the network environment, where the way of college English teaching is more efficient and convenient, the role of teachers has changed, and the whole college English teaching has shown a new development trend.

Adapting to the new social environment, our college English education has been reformed constantly. In terms of college English teaching facilities, many institutions are basically equipped with multimedia network classroom. As a result, teachers can make full use of the multimedia technology to increase students' interests in English learning while widening the channels of learning English in the course of college English teaching.

Now, the network has become an important part of our living and production. The full use of network technology helps to improve the quality and effectiveness of education, so its advantage and role we can not ignore.

In college English teaching, the use of multimedia and network by teachers can have a great help to mobilize the enthusiasm of students. For example, in the college English reading teaching, teachers can use the network and multimedia to display the text, and play the tape of this text' recording, or analyze the important long sentences during the text reading process, or introduce some extracurricular cultural knowledge or cultural phenomenon according to the text. Teachers can give students more intuitive explanations through multimedia and network, providing them the visual and auditory sense of the text.

However, it is worth noting that the successful application of network and multimedia teaching requires teachers to make a teaching design. Otherwise, students will feel bored, and will form a misconception that the relevant English knowledge is accessible on the internet where they can learn it by themselves.

Under the network environment, the role of English teachers has changed. The role of teacher as the guider and promoter is more and more obvious, and this change has produced different effects in the college English teaching.

\subsection{Teachers as guiders and promoters}

Under the network environment, more and more teachers use the network and multimedia technology to help teach, and so it is in the college English teaching. In such circumstances, the role of teachers also should change, which the function of teachers turns from the authority of knowledge into students' learning tutors and collaborators. In the process of college English teaching, teachers generally use the PPT to show the knowledge, and teaches mainly in the form of a combination of problems and content.

For example, on the premise of students' preview, teachers explain the article, and then, ask some questions about the article, such as: (1) the main idea of this article; (2) let students find out 
the sentences they do not understand; (3) their thoughts about the article. First, teachers demonstrate these questions to students step by step, guiding the students to think. In this process, the role of teacher as a guider is very obvious. With the guidance of teachers, the students think deeply about these questions when they read the main parts of the article. After that, the students answer the questions. Finally, the teacher makes a analyze and summarize, and present some knowledge points which embodied in this articles on the PPT.

At the end of the lesson, according to the article, the teachers leave students some new questions which students should think about after the lesson and give the answers in the next lesson. The students can search the relevant knowledge through the internet or other instruments, and then form the answers with their own ideas. In this process, the collection of information by students themselves is a very critical step. Viewed from the whole process of college English teaching, we can see that teachers play more as roles of guiders and promoters.

\subsection{Teachers as organizers and managers}

One of the main purposes of university education is to enhance students' ability of autonomous learning, so it is with the English teaching. And the Internet provides them with a fundamental environment for the improvement of students' self-learning ability. With the help of the internet and multimedia, college English teachers can organize and manage students better. Under this condition, teachers in the college English teaching play the roles of organizers and managers. As organizers and managers, the functions of teachers in the college English teaching are: (2) teachers should select appropriate learning resources based on the teaching content, knowledge requirements and the actual situation of students; (2) teachers assign the tasks according to the teaching materials and organize the students to learn on the internet; (3) according to the college English teaching materials and the requirements of the school mission, teachers should assign the tasks randomly to the students in groups, and organize students to make full use of network resources to access relevant information and make some notes; then, the students carry out English activities through the use of multimedia technology.

During the process of college English teaching, as organizers and managers, the teachers put forward the key knowledge points, which make full use of the students' autonomous learning ability. However, under the network environment, teachers can not rely too much on the internet and multimedia, which can contribute that they let the students learn the knowledge all from the internet in the class. Instead of these, they should organize the teaching contents and students' classroom activities more creatively with the help of internet. At the same time, students can not rely entirely on the network and reluctant to think independently. Under the network environment, the college English teaching needs both the teachers and students' participation and cooperation.

\section{Summary}

At various times, students all have acquired the independent learning capability at the university stage. The traditional college English teaching has its own advantages and disadvantages. At this internet age, the teaching of college English has changed a lot, and the role of teachers has also changed. In terms of teachers' roles, they changed from previous speakers and mentors to active guiders and organizers, all of which have played a positive role in college English learning. With the development of the times, the role of teachers must change. Besides keeping pace with the times, this change also should take consideration of the specific circumstances. All in all, no matter how the teacher's role changes, as long as it consists with the development trend of different times, and with the different levels of students, it will always help improve the students' English learning. Teacher is always a kind of great profession, and the responsibility of teachers will never change.

\section{References}

[1] Wang Jinlong, Cen Xu, The Role Change of College English Teachers under the Circumstance of Web-Based[J], Journal of Southwest University of Science and Technology, pp:65-68+92,2008. 
[2] Peng Linyang, College English Teacher 's Role Orientation and Its Realization under Network Condition[D], Hunan Normal University,2012.

[3] Qu Yinghua, The Orientation of Role of Teachers in College English Teaching under the Network Environment[J], Oversee English, pp:48-49, 2016.

[4] Ji Junli, The Role Change of College English Teachers in Network Environment[J], The Testing and Evaluation, pp:83-85,2016.

[5] Dai Xia. [J]. The Role of College Teachers in the Teaching of College English Multimedia, Gansu science and technology aspect, pp:21-22+128, 2012.

[6] Chen Zhan, The Change of College English Teachers' Role and Teaching Mode under the Network Multimedia Environment[J]. Journal of jilin institute of education, pp:74-75,2012.

[7] Wang Ruiyao, On the Role of College English Teachers in Network Self - regulated Learning Environment[J]. Journal of Language and Literature Studies, pp:88-89+95,2012.

[8] Ye Qingfang. The Construction of Diversified Role of College English Teachers in Multimedia and Network Teaching Environment[J], Information and Communication, pp:144-145, 2013. 